\title{
CLINICAL MANIFESTATIONS SEEMED MORE SEVERE AMONG PATIENTS WITH ANTIBODY 4-FOLD OR A GREATER INCREASE IN TITER BOTH AGAINST PH1N1 AND AGAINST SEASONAL INFLUENZA THAN THOSE WHOSE ANTIBODY 4-FOLD OR GREATER INCREASE IN TITER WAS ONLY AGAINST ONE TYPE OF SEASONAL INFLUENZA
}

June 24, 2013

To the editor

In 2009, after an emergence of pandemic influenza A(H1N1) (pH1N1), one of our serological investigations showed 23 students whose paired serum antibodies simultaneously presented 4-fold or greater increase in titer both against $\mathrm{pH} 1 \mathrm{~N} 1$ and against seasonal influenza (SI). This caught our attention and in order to further understand clinical features of these cases, a case control study was conducted. From October 2009 to September 2012, we collected the acute and convalescent phase serum samples from patients whose throat swabs were positive for $\mathrm{pH} 1 \mathrm{~N} 1$ or SI by real-time reverse transcription polymerase chain reaction $(\mathrm{RT}-\mathrm{PCR})^{5}$. The patients' information, including clinical symptoms, selfprotect measures, and social activities after illness, was also collected through inspecting medical records, and interviewing face to face or by telephone.

Paired blood samples were used to test antibodies against 2009 pandemic $\mathrm{A}(\mathrm{H} 1 \mathrm{~N} 1)$ influenza virus and four kinds of seasonal influenza subtype virus (H3N2, H1N1, By, and Bv), which were detected by Hemagglutination inhibition (HI) assays. The influenza viruses used were A/GuangdongLiwan/SWL1538/2009 (H1N1), A/TianjinJinnan/15/2009 (H1N1), A/FujianTongan/196/2009 (H3N2), B/JiangxiXiushui/32/2009 Victoria, and B/Guangdong Xindong/134/2009 Yamagata. The HI assay was performed using a standard technique ${ }^{2}$. Serum samples were treated with receptor destroying enzyme to remove nonspecific hemagglutination. Serum samples were diluted in serial two-fold dilutions from 1:10 to 1:640 and then mixed with chicken red blood cells and the virus strain. HI titer was determined as the highest dilution of serum which showed hemagglutination inhibition.

During the study period, a total of 2,079 paired blood samples were collected, of which 68 cases (3.27\%) whose antibodies were simultaneous 4-fold or greater increase in titer against $\mathrm{pH} 1 \mathrm{~N} 1$ and SI. Among the 68 cases, the sex distribution was $61.76 \%(\mathrm{~N}=42)$ male and $39.14 \%(\mathrm{~N}$ $=26$ ) female, the age ranged from five to 81 years old (median age $=$ 20), the patients had fevers ranging from $37.5^{\circ} \mathrm{C}$ to $40.6{ }^{\circ} \mathrm{C}$, the disease course lasted from two to 11 days. Primary clinical symptoms were a sore throat $(65 / 68,95.59 \%)$, a cough $(37 / 68,54.41 \%)$, and a headache $(31 / 68,45.59 \%)$. The proportion of patients who had arthralgia, nausea, vomiting and diarrhea was $8.82 \%(6 / 68), 7.35 \%(5 / 68), 4.41 \%(3 / 68)$, and $4.41 \%(3 / 68)$, respectively.

Of those whose antibodies presented 4-fold or greater increase in titer only against one subtype of SI, 136 cases were selected into a control group as a 1:2 match according to the following matching criteria: onset date (+/- 20 days), age (+/- 4 years), and sex. Compared to the control group (136 cases), the proportion of patients with a fever $\geq 38.5{ }^{\circ} \mathrm{C}$, disease course $\geq 5$ days, and clinical symptoms $\geq$ three episodes were significantly higher $(p<0.05)$ among the case group $(68$ cases $)$ (Table 1$)$

Table 1

Comparing the clinical characteristics between case group (68 cases) and control group (136 cases)

\begin{tabular}{|c|c|c|c|c|c|c|}
\hline \multirow{2}{*}{ Clinical symptoms } & \multicolumn{4}{|c|}{ Case group Control group } & \multirow{2}{*}{$\mathrm{x}^{2}$} & \multirow{2}{*}{$p$} \\
\hline & No. & $\%$ & No. & $\%$ & & \\
\hline Fever $\geq 38.5^{\circ} \mathrm{C}$ & 26 & 38.24 & 33 & 24.27 & 4.30 & $0.04 *$ \\
\hline Disease course $\geq 5$ days & 19 & 27.94 & 14 & 10.29 & 10.41 & $0.00^{*}$ \\
\hline Cough & 37 & 54.41 & 66 & 48.53 & 0.63 & 0.43 \\
\hline Sore throat & 65 & 95.59 & 129 & 94.85 & 0.05 & 0.82 \\
\hline Headache & 31 & 45.59 & 55 & 40.44 & 0.49 & 0.48 \\
\hline Nasal congestion & 23 & 33.82 & 40 & 29.41 & 0.41 & 0.52 \\
\hline Rhino rhea & 17 & 25.00 & 32 & 23.53 & 0.05 & 0.82 \\
\hline Sputum production & 14 & 20.59 & 25 & 18.38 & 0.14 & 0.70 \\
\hline Fatigue & 23 & 33.82 & 41 & 30.15 & 0.29 & 0.59 \\
\hline Myalgia & 9 & 13.24 & 16 & 11.77 & 0.09 & 0.76 \\
\hline Chills & 11 & 16.18 & 15 & 11.03 & 1.08 & 0.30 \\
\hline Arthralgia & 6 & 8.82 & 15 & 11.03 & 0.24 & 0.63 \\
\hline Nausea & 5 & 7.35 & 7 & 5.15 & 0.40 & 0.53 \\
\hline Vomiting & 3 & 4.41 & 5 & 3.68 & 0.07 & 0.80 \\
\hline Diarrhea & 3 & 4.41 & 2 & 1.47 & 1.64 & 0.20 \\
\hline $\begin{array}{l}\text { Clinical symptoms } \geq 3 \\
\text { episodes above }\end{array}$ & 32 & 47.06 & 43 & 31.62 & 4.65 & $0.03^{*}$ \\
\hline
\end{tabular}

$* p<0.05$

Taken together, we reported that of the 2079 influenza patients, 68 cases were found to have simultaneous 4 -fold or greater increase in serum antibody titers against $\mathrm{pH} 1 \mathrm{~N} 1$ and SI, these cases appeared to have more severe clinical pictures, including higher fever, longer disease course and more episodes of clinical symptoms. A possible explanation for this might be that these cases presented with a co-infection. Before emergence of $\mathrm{pH} 1 \mathrm{~N} 1$, co-infection has been proved to exist in seasonal 
LI, T. \& WANG, M. - Clinical manifestations seemed more severe among patients with antibody 4-fold or a greater increase in titer both against pH1N1 and against seasonal influenza than those whose antibody 4-fold or greater increase in titer was only against one type of seasonal influenza. Rev. Inst. Med. Trop. Sao Paulo, 56(2): $183-4,2014$.

influenza. For example, NISHIKAWA et al. found a patient who was simultaneously infected with seasonal influenza $\mathrm{A}(\mathrm{H} 1 \mathrm{~N} 1)$ and $\mathrm{A}(\mathrm{H} 3 \mathrm{~N} 2)$ during the epidemic of $1981^{3}$. In 2006, TODA et al. isolated the A/H3 and $\mathrm{B}$ viruses from an influenza patient ${ }^{4}$. In addition, GOKA et al. also found co-infection was associated with higher risk of admission to ICU/ death ${ }^{1}$. Due to virus isolation not being conducted among our samples, more evidence regarding $\mathrm{pH} 1 \mathrm{~N} 1$ and SI needs to benefit from molecular virology research in future.

Tiegang LI Ming WANG

Correspondence to: Ming Wang, M.D, Guangzhou Center for Disease Control and Prevention, Guangdong Province, 510440, China. E-mails: wangming@gzcdc.org.cn tiegang1977@126.com

\section{REFFERENCES}

1. Goka E, Vallely P, Mutton K, Klapper P. Influenza A viruses dual and multiple infections with other respiratory viruses and risk of hospitalisation and mortality. Influenza Other Respi Viruses. 2013;7:1079-87.

2. Kendal AP, MacDonald NE. Influenza pandemic planning and performance in Canada, 2009. Can J Public Health. 2010;101:447-53.

3. Nishikawa F, Sugiyama T. Direct isolation of H1N2 recombinant virus from a throat swab of a patient simultaneously infected with $\mathrm{H} 1 \mathrm{~N} 1$ and $\mathrm{H} 3 \mathrm{~N} 2$ influenza A viruses. J Clin Microbiol. 1983;18:425-7.

4. Toda S, Okamoto R, Nishida T, Nakao T, Yoshikawa M, Suzuki E, et al. Isolation of influenza $\mathrm{A} / \mathrm{H} 3$ and $\mathrm{B}$ viruses from an influenza patient: confirmation of co-infection by two influenza viruses. Jpn J Infect Dis. 2006;59:142-3.

5. Wu W, Kang X, Bai Z, Liu L, Li J, Wu X, et al. Detection of pandemic influenza A/H1N1/2009 virus by real-time reverse transcription polymerase chain reaction. J Virol Methods. 2010;165:294-6. 